\title{
Theorizing Mamanuan Diaspora: from Vanishing Mediator to Performative Indigeneity
}

\author{
Jan Gresil S. Kahambing \\ Leyte Normal University, Tacloban City, Philippines, vince_jb7@hotmail.com, ORCID: \\ 0000-0002-4258-0563 \\ First published July 12, 2019
}

\begin{abstract}
The Mamanuas of Basey, Samar have been in an itinerant state since the 1950s. Their indigenous experience can be capped in the term 'diaspora,' which pictures their plight as dispersive habituation, moving from town to town away from their homeland. In a recent study which this paper hinges upon, the concept of diaspora can no longer work and is argued to imperatively function as a vanishing mediator so that indigeneity must come to mean as a constant identity of becoming. Following from such a theoretical lens, this paper delves again into the concept of 'diaspora' in the Mamanuan indigenous experience to argue further that its act of mediating functions as performative indigeneity. To do this, the paper runs in three parts: first, it plots the Mamanuan diaspora experience; second, it briefly reiterates the core argument of diaspora as vanishing mediator; and finally, it theorizes on a concept of what Judith Butler calls 'performative indigeneity' that takes its form from the mediation of an indigenous diaspora experience.
\end{abstract}

Keywords: Mamanwa, Diaspora, Vanishing Mediator, Performativity, Indigeneity, Butler

\section{The Mamanuan Diaspora Experience}

The Mamanuas of Basey, Samar, whose diaspora this initially study plots, are indigenous migrants. ${ }^{i}$ Generally, the Mamanuas are descendants of the Aetas or Negritos who came to the Philippines the earliest (30,000-25,000 BC) as nomadic hunters and foragers (Burton, 2003; cf. Stoneking, 2008). They speak the Proto-Manobo language (cf. Dyen, 1965/1963; Pallesen, 1985) and sought habitat in Agusan del Norte, Surigao del Sur, and Surigao del Norte. They are the original inhabitants of the region (see Garvan, 1964; Almeda, 1993; Tiukinhoy, 1997; Trinidad, 2012). On the outset then, before we understand their migrancy, it is important to note that the Mamanwas first set-up home in forestal uplands along these regions because these have rich resources like feral plant food and wild animals. There are called Mamanwa or first forest dwellers as stemmed from man (first) and banwa (forest).

The migrancy (and consequently, the diaspora) of the Mamanuas of Basey can be situated from the bigger picture of the Indigenous Peoples (IPs) in the Philippines. They are lumads or the indigenous in Mindanao that are in the state of constant struggle in terms of habitat, proving henceforth their nomadic lifestyle of going from one place to another.

(c) AesthetixMS 2019. This Open Access article is published under a Creative Commons Attribution Non-Commercial 4.0 International License (http://creativecommons.org/licenses/by-nc/4.o/), which permits non-commercial re-use, distribution, and reproduction in any medium, provided the original work is properly cited. For citation use the DOI. For commercial re-use, please contact editor@rupkatha.com. 
This struggle, however, as reflective of their indigeneity incites the intersections of sociopolitical factors. The essential plot that substantiates this struggle points to their diasporic experience. Between the bigger picture of the Indigenous struggle and the particular struggle of the Mamanwas, there are a few 'causative factors' (Burton, 2003) why diaspora as a form of nomadic, if not exilic, experience succeeds.

First, it is important to note that Mindanao has rich resources not only in terms of land produce but also of timber and minerals. It is considered as a "land of plenty." This gained a special interest in the eyes of mining companies and businesses that attend to logging and timber-distribution. The slow but constant taking over of these companies took away their ancestral domains, forcing them to move and leave their communities. In fact, not only large scale businesses sparked interest for these lands but also 'landless farmers from Luzon and the Bisayan regions' who mass-migrated in the region through settlement programs (Burton, 2003). As such, 'the incursion of heavy industry into their [the Mamanuas'] heritage lands had forced many to settle in the hinterlands, where they continue to practice their customs and traditions (Linguistic Society of the Philippines, 1991).' Moreover, what hastened land dispossession that proves as a crucial factor in the diaspora of the Mamanwas is their general attitude. The Mamanwas are a generous and peace-loving people (Masinaring, 2011) so they gladly accept simple barter exchanges: for example, a can of sardines for a piece of their land. The Mamanwas then moved farther to the hinterlands when most of their ancestral land is bartered for a few pesos or payments in kind. In fact, their generous attitude even allowed them to give for free since, at that time, resources were abundant.

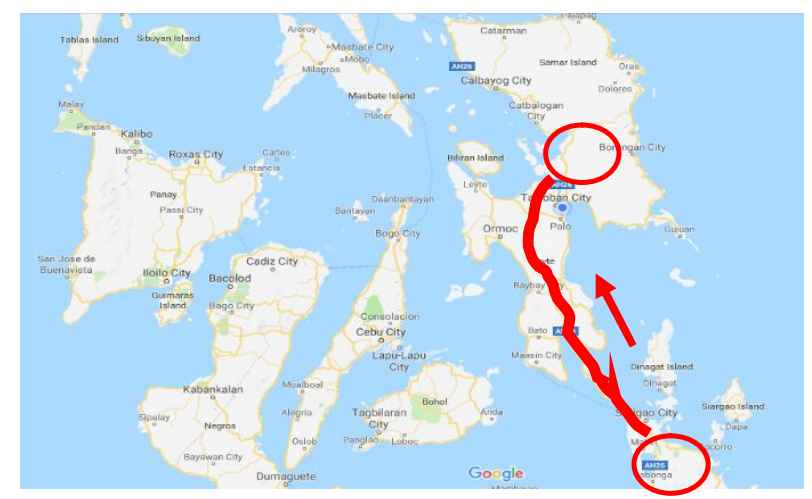

Figure 1. Movement from Surigao to Mabini, Samar. (Raw Image captured from Google Maps)

Second, the Philippine Republic's early establishments found conflict in the political unrest from Communist Rebel groups. Insurgency did massive displacements of the IPs since they were suspected of giving sanctuary to the New People's Army (NPA) or are even regarded as NPA themselves (Burton, 2003, 17). This led to the destruction of the IPs' settlements, their farms and domesticated animals (Burton, 1992). Added to the issues about open-pit mining and logging operations then are the militarizations from the rebellous violent confrontations between the New People's Army (NPA) and Moro National Liberation Front (MNLF) and the government. The IPs, including the Mamanwas, are caught in between this struggle. These are prevalent problems that 
expose the precariousness of the Indigenous Peoples (IPs) in the Philippines (Eder, 1994), leading to their diaspora.

Moreover, there are good reasons why Leyte and Samar come to mind as a greener place or the tempting 'other side' of the narrative. Masinaring (2011) reports on how the Mamanwas, being nomadic and 'highly mobile,' would often brag about going to Leyte and Samar, advertising its status as a better region. In this regard, as part of the sociopolitical context, Ponce (2018a) provides an economic motive: the gathering of rattan (uway) or panguway remains an undisputed Mamanwan practice and there is abundance of rattan in Leyte and Samar. Additionally, Southern Leyte is the closest passage towards the Eastern Visayas Region through Panaon Island. Through this route, the Mamanwas of Basey arrived first in Mabini, Samar, in the 1950 .

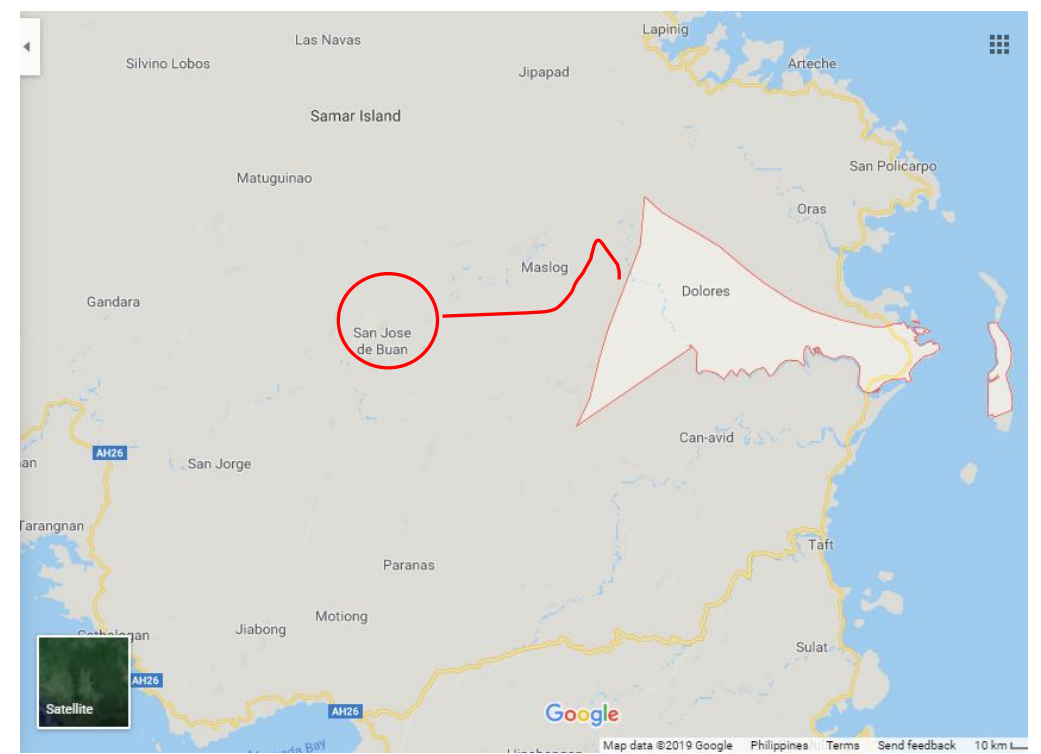

Figure 2. San Jose de Buan to Dolores (Raw image from Google Maps)

After some initial movements in the areas of Mabini, they roamed around and reached San Jose de Buan. However, since the militarization and insurgencies were spread not only to Mindanao but also to the whole archipelago, the Mamanuas again faced the threat and disturbance of armed conflict. In fact, the resettlements of the landless farmers to Mindanao too was a product of the uprisings in the Luzon and Visayas regions. They were again suspected as accomplices of the rebels so they moved to Dolores, Eastern Samar and settled there for a long time until the year 200o. After this year, the Mamanuas again initiated movements, owing to the messy socio-political context that haunted them and the already-lessening resources.

For them, however, the next transition is a difficult one. First, the Mamanuas have ingrained their lifestyles in Dolores for decades. And second, they have to face the dilemma of splitting their growing families. Some moved to the island province of Biliran where they stayed in the municipality of Almeria. Then some others went to the 
hinterlands of St. Bernard. During this time, resources may not already be as abundant as before and most lands have already been owned. This led some to go back to Mindanao and others who returned to Basey in the year 2012.

On the outset, this indigenous experience appearing as a linear storyline must not be taken as the sole plot of their plight. This is to give way to the understanding that the Mamanuas of Basey are not the only Mamanuas who are dispersed. Instead, there are other Mamanuas in Leyte that do not follow their movements and made their own in the years to come. It is a Mamanuan diaspora in the grand scheme and it moves from a singular narrative.

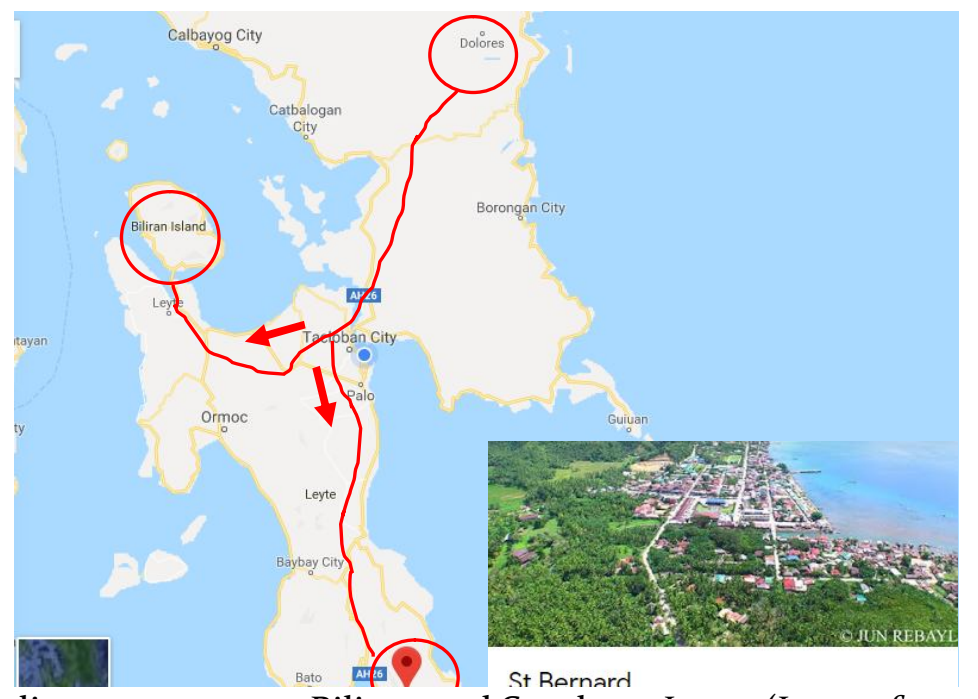

Figure 3. Split movements to Biliran and Southern Leyte (Image from Google Maps)

Another (nonetheless, related) account traces the origin of the Mamanuas in 'Agusan del Norte, Surigao del Norte, Surigao del Sur, Panaon Island, and in the mountains of Southern Leyte' but not in Basey, Samar (Linguistic Society of the Philippines, 1991). The Mamanwas of Basey might be moving on their own and are not included in this study, but this shows, alternatively, that there are already Mamanuas also in the small island of Panaon and the mountains of Southern Leyte. Although the specific sites in Panaon Island and the mountains of Southern Leyte were not mentioned, fortunately, recent researches were disseminated to pinpoint these locations, namely, the municipality of San Francisco in Panaon and the hinterlands of St. Bernard. Studies then about the residences of the Mamanuas in different places of the region are extant and offshoots from the Mamanuan diaspora experience.

Picardal (2017) conducted a study of the Mamanwas of Almeria, Biliran. He finds that although there is flexibility in terms of the nomadic lifestyle that the Mamanwas imbibed in their habituations, cultural influences as a social structure inevitably affect their way of life. Education, for example, hastened the acculturation of the young. And the religious orientations of the Catholic Church and Iglesia ni Kristo (INC) slowly replaced their 'indigenous manner of worship' (Picardal, 23). 
Ponce (2018b) also noticed how social influences affect the indigenous religious rites of the Mamanuas so she made a study in Panaon island, which is now connected to mainland Southern Leyte through a bridge in Lilo-an. Ponce's 'Hitso: Food Ritual and Changes' (2018b) does an ethnographic study of the migrant Mamanwas of Brgy. Pinamudlan, San Francisco, Southern Leyte, and shows how their food culture and its symbolic ritualization links to their religious practice. She finds that the Mamanuas in San Francisco sees food as 'a means to pass blessings and healing, an avenue for showing miracle, and for socialization' and this is slowly disturbed through various ecological and socio-cultural changes. Although Hitso - using food within the belief system - remains to be a stronghold that ties the nexus of food and religion rites of the Mamanuas, Ponce points that their migrant lifestyle produces effects that prove precarious to their cultural rites.

Further correspondence with Ponce ascertained that the Mamanwas of Panaon island are part of a few who do not belong to the majority of Mamanwas in Samar. A few made their own movements in Southern Leyte and even to some parts of Mahaplag, Leyte. This is due to the fact that, in one of many economic reasons, rattan is also abundant in Panaon island. During the landslide in St. Bernard in 2006, some of the Mamanwas in San Francisco transferred to St. Bernard to take advantage of the housing projects initiated by a Korean religious group. To clarify, however, with no permanent settlement, there were already a few Mamanwas in the mountains of Southern Leyte during this time, and this includes the hinterlands of St. Bernard. Their number increased when the Mamanwas of San Francisco came after the landslide.

Retome (2018) then explores the Mamanwas of St. Bernard, Southern Leyte, concerning their state of life, i.e. demographic profile, source of income, family structure and its connection to their experience and sanitation, and facilities and housing materials. According to her study, the Mamanwas of St. Bernard have no sustainable livelihood to provide for them their daily sustenance and their means of finding food depends heavily on hunting, gathering of medicinal plants, collecting wickers, orchids, root crops, and extracts/syrup from the forest. There is also no family planning since no limitation is put in terms of childbearing. Facilities and house materials are not sturdy and only 3 out of 37 Mamanuan children goes to school.

Retome, during the $2^{\text {nd }}$ International Conference on Philippine Studies (2018), clarified that the Mamanwas of St. Bernard do not follow from the Mamanwas of Basey. This is confirmed by the Mamanwas of Basey in their claim that they are aware of the Mamanwas of St. Bernard and that they are their ig-agaws or cousins (in broad terms, it means relatives). Further correspondence with her revealed that the Mamanuas are no longer in the mountains due to some conflicts with the Koreans.

The Mamanuan diaspora experience is one that is, therefore, a locus of precarity. Those who are now settled back in Basey, Samar are still facing not only economic problems but also of habitat. With the added threat of climate change, the Mamanuas, even with their indigenous ways of coping with weather changes and observations of nature, are still in a precarious condition. In fact, in what may be a result of trauma from the previous super 
typhoon Yolanda (International name: Haiyan) that hit most devastatingly Leyte and Samar, any storm that resembles in any way to the typhoon in terms of damage and structural disruptions in their homes are seen as threats. Bonifacio (2018) reports how their tribal leader immediately sought help for the displaced families. The areas of their homes were flooded so they collectively transferred to their small chapel for safe grounding.

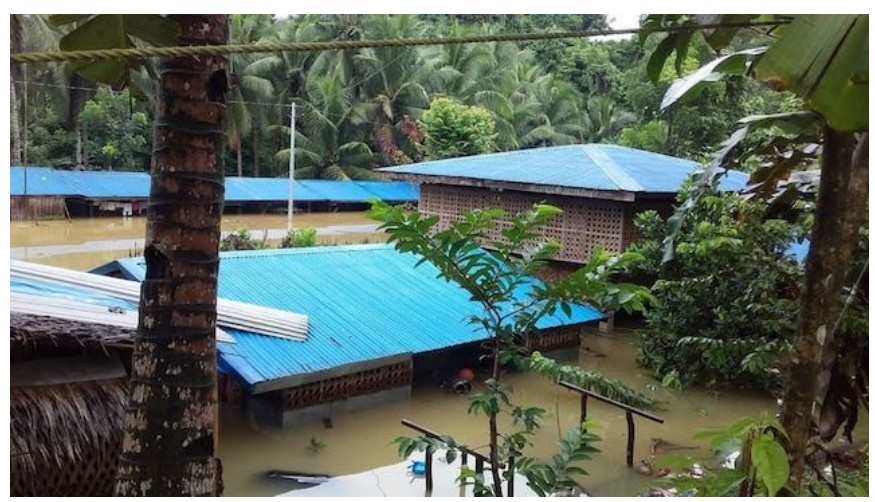

Figure 4. Flooding on the Mamanwa site, December 29, 2018. Photo courtesy of Allan Velarde of One Fm 96.7 Tacloban as retrieved from Rappler

With the prospect then of a precarious diaspora experience, is the necessary solution to bring the Mamanwas back to Surigao? Given this image of diaspora that presses the solution of bringing them back to their homeland, one can presuppose that the underlying diagnosis goes in the same manner as originally meant with the Jews as a dispersed people whose struggle is to go back to Israel. The following section briefly reiterates how this is not viable anymore.

\section{Diaspora as Vanishing Mediator: Revisited}

In a recent article, the notion of diaspora can no longer work as the sole solution to the plight of the Mamanwas and must instead act as a vanishing mediator (Kahambing, 2018). The concept diaspora has become a recurring modifier, often heard in reporting the migrancy of the Mamamuas of Basey. This study is part of an ongoing long-term project of documenting the Life \& Culture of the Migrant Mamanwas of Basey, Samar.

Espada (2018), being the head of the project, reported and referred to the documentation as an indigenous experience of diaspora, tied in hindsight with the understanding of their migrancy. However, the argument of diaspora as vanishing mediator precisely prohibits this since it essentially gives the impression that they should be brought back to Surigao. The proposal lens, however, does not totally negate the view of their diasporic status but views it alternatively as a vanishing mediator. 


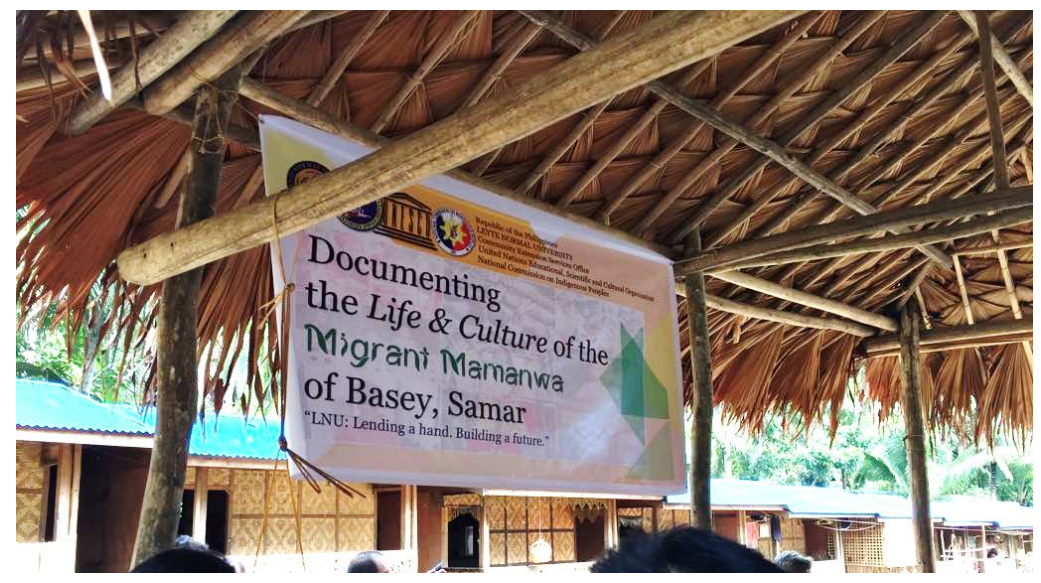

Figure 5. Tarpaulin of the Project during the first formal visit to the Mamanwa Tribe in Basey, 2017. The project is in partnership with UNESCO and NCIP (see logos)

The vanishing mediator in this regard functions basically as a mediating catalyst of permitting changes between two concepts, after which it vanishes. The concept is exhausted from the analyses of Jameson (1973), Žižek (2009), Balibar (2003), and Boer (2001) whose fundamental take on the mediator resides in different subjects: the Protestant Ethic for Jameson, Christ and Hegel for Žižek, the European intellectuals' task of translation for Balibar, and Postcolonial criticism for Boer. Each of these subjects performs a mediation of an old view that passes on to a new one; and after this mediation performs its task, it vanishes since there is no more reason to further its cause. This allows for social movements, for instance, if we take from Boer's logic of postcolonialism as vanishing mediator, to halt its resistance so long as what it asks is already completed. In such case, the recent proclamation of same-sex marriage legality in Taiwan and Asia by extension as a first (Hollingsworth, 2019), for instance, signals the end of an old sociopolitical context and by then, the particular small-scale resistances that led to its passage would have already vanished and will soon vanish in the future. There is, however, a crucial point that explains this vanishing act: vanishing does not mean complete annihilation because the mediation is still a subsumed element in the social logic of the new structure (cf. Dean, 2006; Charnes, 2000; Arditi, 2014). In terms of the new Mamanuan identity that is emancipated in Basey, Samar

What this concretely means is that some of the practices would have been gone already: hunting, tilling, foraging, and so on. For the Mamanuas of Basey - and take note of the genitive - the inhabitants must have already adapted from the place, so much so that the concept of diaspora, the want for going back to their land, is no longer viable to be able to fully adapt to such place. That is to say, that something unique happens here: the cultural adaption, or acculturation, is interestingly a new form of identification (Kahambing, 2018).

The research from the Linguistic Society of the Philippines (1991) backs this analysis: 'some practices have fallen by the wayside, such as traditional hunting by bow and arrow. 
The Mamanwas receive some of their subsistence from other groups with whom they have forged labor agreements.' A radically new Mamanuan identity, therefore, is best catered from the vanishing point of their diaspora experience. To further support the idea that bringing them back to their homeland is not enough, two points prove vital. First,

In 1986, the apostolate groups in the Diocese of Tagum and other NonGovernment Organizations (NGOs) working for indigenous peoples along with the office of the mayor, talked with the Mamanua (not of Basey, but of Kitcharao), and agreed to fund them into going back to Kitcharao, their then settlement. This is, to give a historical account, an example of a resolved solution to the problem of diaspora - that they will be sent to their homeland. However, the apostolate groups and other agencies realized that the solution is "futile," because "every year, they return to beg (Masinaring, 2011)." The conditions are not the same anymore, largely due to the fact that resources are no longer plenty and there are good reasons why they have left their homeland in the first place (Kahambing, 2018).

Second, the recent study of Balacuit et.al (2018) on the current status of the Mamanwas of Surigao itself, their associated place of origin, revealed how they are still living in poverty. This disproves the assertion that they must be assisted back home to Surigao. The Mamanwas in Surigao are still not better off compared to those in other parts of the country. They have no family planning, poor educational attainment, and thus most are working at minimum wage pays. Their reliance on traditional ways of subsistence such as farming or fishing but with lack of advanced technological tools does not guarantee for growth and improvement.

From this understanding of diaspora as vanishing mediator, this paper now theorizes the further assertion that within the recurring themes of habitat, exile, and precarity, the Mamanuan diaspora experience as a mediator can be explicated further as what Judith Butler calls "performative indigeneity."

\section{Diaspora's Mediation as Performative Indigeneity}

The Mamanuan diaspora experience, as argued, will soon vanish in the future as a mediator that catered to their settlement and emancipation of a radically new identity in Basey. Interestingly, this can be associated as a metaphor to the Mamanuas' nonceremonial burial practice in which they merely leave the dead as they move. In this sense, the slowly vanishing practices of the forest people such as foraging and tilling might also be non-ceremonial with the current practices silently replacing the old ones. In going towards Butler's work, it is important to base from a fundamental concept of indigeneity that is always about movement: if diaspora will soon vanish after its mediation but still remains in the (socio-cultural or political) logic of the new structure, then it has to be taken note that indigeneity must allow the emancipation of identity in a state of constant flux. The dedicated ethnographer of Aboriginal peoples who recently died, Deborah Bird Rose (1946-2018), says: 
One of the most basic of all human questions: who are you? This is not a question that can be answered with a name nor can it be answered satisfactorily in words. Rather, the question requires qualitative demonstrations. Answers emerge in the lived experience of relationships developed in shared time and place. Ultimately, answers are a sharing of perceptions, attitudes, experiences, and, I think, compassion. (Rose, 2009/1992, 26).

For Venkateswar, et. al. (2013), Rose pictures an indigeneity that is, at once, 'an identity that is continually in flux and is determined not by some original state of purity but by the relationships between peoples.' It speaks of 'a process of accommodation based on a relational understanding of indigeneity (Venkateswar, et. al, 2013).' Smith (2011) also noticed how indigeneity is often seen as 'static, unchanging and inflexible' in contrast to the borderlands which is 'the place of change, indeterminacy, and flux.' This view that indigeneity is being tied to a place, that is, of being 'local...or rooted' is similarly found in Cox (2007) and is placed in contrast to diaspora. But it is from the appeal of Harvey and Thompson (2005) that a differing view of indigeneity moves away from this stasis and instead thinks of it as 'always having been about movement.' That is to say, that the concept of diaspora in this regard is not an antithetical concept to indigeneity; rather, diaspora becomes an inherent performativity to indigeneity.

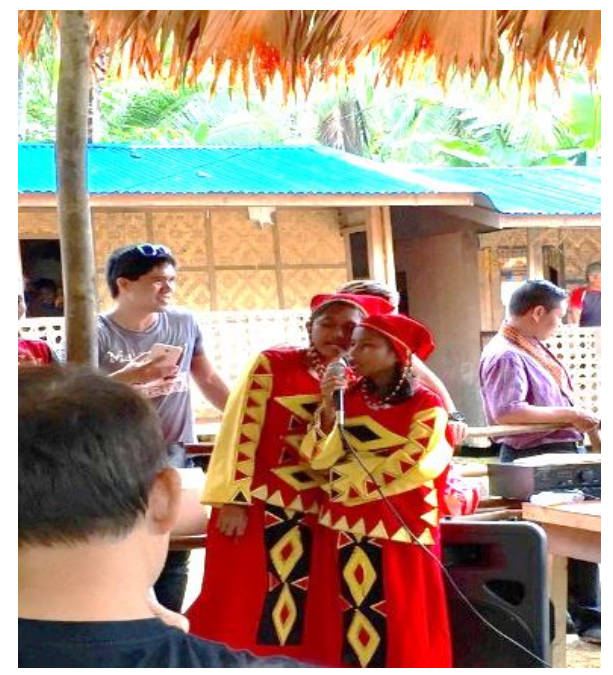

Figure 6. Mamanwa children singing during the visit

Herein lies the notion of Butler's performativity: it is one thing to perform indigeneity as a role or performance. It is quite another to experience such indigeneity as performative. The two are not the same. During, for example, the visit of the researchers of Leyte Normal University for the project, the Mamanwas got dressed in their tribal attire and performed by singing and dancing - that is, on the one hand, a performance. Taking on a role, an act, is a performance, and its duration and number is dependent upon the recurrence of an event. But performativity is different since it far surpasses the act of playing a role at a particular time, in a particular place. In fact, the tribal attire worn by the Mamanwas were not purely their own: some of its textile designs and the intangible 
knowledge of craftsmanship in making it does not point to a purely original Mamanwan appearance, but is already a product of their interactions with the other indigenous groups - with the Manobo, more closely. This is made possible by the Mamanwas' acculturation from other IP groups such as the Agusan-Surigao Manobos (Tomaquin, 2013). Also, that the Mamanwas dress for an act is part of the tourism project of Spark Samar (Amazona, 2016). Performativity, on the other hand, essentially projects a deliberation of a politicized identification: it is fueled by repetition and forms itself by sharing a way of life and thinking.

The deliberate performative indigeneity in Butler, more particularly, points to the 'invocation of an identity for the purposes of political resistance to a hegemonic threat of erasure or marginalization' (Butler and Scott, 1992, 109). This is made evident by the fact that the Mamanwas are still on the process of 'integration to the Philippine body-politic' (Tomaquin, 2013). There are problems associated with the indigenous in the Philippines mainly because the State still acknowledges them as a minority whose identity is tied to localized ancestral domains, their lives made precarious by the stigma they inherit from rebels against the State. In which case, the Mamanuas, or the IPs in general, are placed in a marginalized position under a national hegemonic practice. Within this perspective, projects that touch on their socio-economic improvement are always fraught with antagonism. For instance, the issues on the project of education are always going to be a problem of prejudice, discrimination, and financial difficulty (Retome, 2018). As Aetas, their physiognomy of black skin and curly hair earned some discriminatory remarks that they are often called Kongkings, a derogatory play of words associated with the giant black ape King Kong, or Mamaws, monsters that frighten children equivalent to that of the boogeyman.

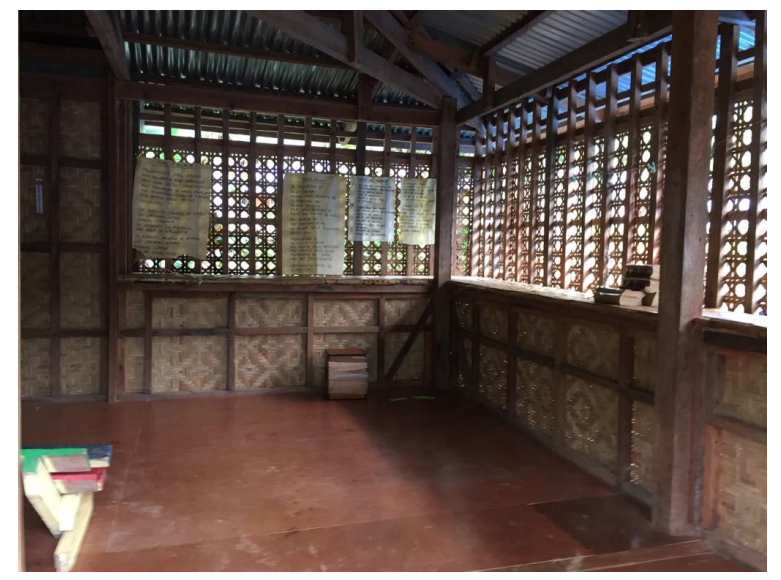

Figure 7. Mamanwa chapel as a small refuge from the flood. One of the papers present the texts of the Lord's Prayer. (Photo taken from one of the visits)

During the Mamanuan diaspora experience, the practice of moving around becomes a political mediation: a performativity of their indigeneity that resists erasure and moves outside the bureaucratic policy of the state. Rifkin (2017) suggested that 'the concept of indigeneity, when fully engaged, foregrounds the presence of a political collectivity (or collectivities) whose existence, inhabitance, and governance cannot be conceptualized as 
an internal matter for domestic policy and whose modes of political organization and expression need not take the form of a nation-state (Rifkin, 56).' Diaspora's mediation then continuously acts a contingent political resistance when it escapes the insurgencies and militarization of the State and communist rebels. It was not merely a performance but a safeguarding of their identity, and a collective constant habituation that forms a dynamic concept of indigeneity. Against the threat of environmental hazards and typhoons, they organize in seeking refuge and help, their chapel for instance, built together with the missionary who evangelizes them.

It is important to note, moreover, that performativity which serves as the mediating act of Mamanuan diaspora embodies precariousness and a way of thinking that opens up on a shared vulnerability status. The Mamanuas projected that they too can collectivize, rather than belong to, a cultural representation of the place, placed within a geological mapping that depends on their indigenousness. They acted upon as a community, as a collective responding to the call of Precarious Life by 'reimagining the possibility of community on the basis of vulnerability and loss' (Butler, 2006, 20). This is part of Butler's sympathy to minority communities 'in the context of their oppression or marginalization' (Watson, 2012), and opens up how 'the relational ties' have 'implications for theorizing fundamental dependency and ethical responsibility' (Butler, 2006, 22; 19-49; italics mine).

In such theorizing, Butler offers the diasporic as a way of thinking a necessary relation to otherness as a condition of being in the world (in the vein of Emmanuel Levinas), which provides 'the condition of possibility for nondiscriminatory modes of governance and political membership (Rifkin, 2017, 51; Italics mine).' The struggle for recognition, which the Mamanwas showed in diaspora, reflects a contingent insistence of identity as it covers both economic and socio-political conditions. As Rifkin follows up: 'the loss of status in relation to the state, "minorities" becoming diasporic, serves as the primary lens through which to understand the situation...' (53).

By becoming collective and assembling into an indigeneity that goes together, Butler 'extends her longstanding theoretical investigation of performativity further into the realm of political philosophy (Slater, 2018, 4; Italics mine).' Specifically, performativity, for Butler, 'is a salient aspect of radical political life as precariousness entrenches inequality and social immiseration, exacerbating the shared vulnerability of many... (Slater, 2018, 45; cf. Butler and Athanasiou, 2013).' In such collectivizing and sharing of their indigeneity, the Mamanuas' assemblies 'become performative politics when the conspicuous fact of their occurrence alone constitutes a claim or declaration of existence against forms of governance that seek to obscure or eradicate the life of certain groups (Slater, 2018, 4-5).'

Finally, it is crucial to point out that the occurrence of a performative politics from the Mamanuas of Basey constitutes a radical way of resisting that still ties to Butler's idea of non-violent resistance. As Butler (2018) explicates:

Non-violent resistance - In my mind, it's important to keep non-violent resistance alive as a form of political experimentation, as a public statement... The problem, of course, is that many people suspect that non-violence is a very weak political instrument. That it can't really do the job. But there are militant forms of non- 
violence. There are aggressive forms of non-violence. So, when human beings produce a barrier, like a human barrier, that stops the police from being able to deport other people or to protect a strike, it's physical. It's... It's a human obstacle, it's a human barrier, it's strong, it's forceful. It's just not violent.

Here, the Mamanuan diaspora experience becomes an avenue of political resistance against, on the one hand, the military machinations of the State, and on the other, the communist rebellions. It resists the involvement of belongingness to the right-wing propaganda and breaks away from the stigmatization it got from rebels with no permanent addresses. It should be clarified, however, that for Butler, non-violence is 'not the will towards peace, but rather a politics of non-violence is equally one of aggression: [...] there are ways of giving form to aggression that work in the service of democratic life (Çetinkaya, 2019).' It should be remembered that the Mamanwas are, apart from being generous and peace-loving, 'respectful people especially to local civil and police authorities (Tomaquin, 2013, 34).' Their brand of aggression is their performative indigeneity itself, the act of diaspora, the constant habituations of the Mamanuas that albeit do not form a human barricade or take part in the political process of policymaking and the democratization of the State, nonetheless antagonizes the erasure of their identity. Through diaspora, they continually resist being linked to the rebels and resist being totally incorporated to the State militarization during their movements. Even with the selling of their lands and giving way to various forms of land negotiations, they still continually move. In this sense, even economic projects are incorporated within the frame of non-violent resistance. Hence, economic matters, like traveling for resources for livelihood, acquire a theoretical scheme as a 'political institution and a social project' (Cochoy et. al, 2010; cf. Polanyi, 2001/1944). In sum, they preserve their precarious communal identification as performative indigeneity. Only after this can one visualize a contemporary lens through which the Mamanwa diaspora experience is seen as a catalyst of change, that is when it is already subsumed in a radically new emancipatory structure as it vanishes.

\section{Note}

'For purposes of the study, the terms 'Mamanua' and 'Mamanwa' are interchanged to mean the same thing, including its usage as modifiers as in 'Mamanuan' or 'Mamanwan.' Although the term Mamanwa may well stand as a collective noun, this paper regards them as a people in the plural, hence, Mamanwas/Mamanuas.

\section{References}

Almeda, F. (1993). Surigao across the Years. Quezon City: PNHS and Heritage Publishing House.

Amazona, R. (2016, September). Samar's Mamanwa tribe eyes better future from tourism. Philippine News Agency. Retrieved from https://businessmirror.com.ph/samars-mamanwa-tribe-eyes-better-futurefrom-tourism/. 
Arditi, B. (2014). Insurgencies Don't Have a Plan - They Are the Plan. In De la Torre, C. (Ed.), The Promise and Perils of Populism (pp. 113-139). Kentucky: University Press of Kentucky.

Balacuit, C., Quezada, E., Abay-abay, J., Caluban, J., Cedron, L., Corvera, L., Cuadrado, B., Huerte, A.J., Montenegro, G., Portillo, G. (2018). Livelihood and Training Needs of Mamanwa Tribe. International Journal of Current Research, 10(9), 73958-73964.

Balibar, E. (2003). Europe: Vanishing Mediator. Constellations, 10(3), 312-338.

Boer, R. (2001). Introduction: Vanishing Mediators? Semeia: An Experimental Journal for Biblical Criticism $88,1-12$.

Bonifacio, J. (2018). Tribal leader seeks help for displaced Mamanwa families in Samar. Rappler. Retrieved from https://www.rappler.com/nation/21988o-tribe-leader-seeks-help-families-displaced-usmansamar?utm_source=feedburner\&utm_medium=feed\&utm_campaign=Feed\%3A+rappler\%2Fnews+\%28R appler\%3A+News\%29

Burton, E. (2003). Rights to Ancestral Domain: The quest of the Indigenous Communities in Mindanao, Philippines. Ninth Session, Commission on Human Rights, Sub-commission on Promotion and Protection of Human Rights Working Group on Minorities. May 12-16, 2003.

Burton, E. (1992). The Indigenous Communities of Mindanao Amidst Arm Conflict. Report to the National Peace Commission. Research Institute for Mindanao Culture Research Papers. Xavier University, Cagayan de Oro City.

Butler, J. (2006). Precarious Life: The Powers of Mourning and Violence. London: Verso.

Butler, J. (2012). Parting Ways: Jewishness and the Critique of Zionism. New York: Columbia University Press.

Butler, J. (2018). “Non-violent resistance works.” A Talk Europe! Interview with Judith Butler. Retrieved from https://www.youtube.com/watch?v=7c_SdvaP9CE

Butler, J. and Athanasiou A. (2013). Dispossession: The Performative in the Political. Cambridge, UK: Polity Press.

Butler, J. and Scott, J. W., Eds. (1992). Feminists Theorize the Political. London/New York: Routledge.

Cetinkaya, H. (2019). Judith Butler and the Ethics \& Politics of Non-Violence. The New Pretender. Retrieved from https://new-pretender.com/2019/02/17/judith-butler-and-the-ethics-politics-of-non-violencehasret-cetinkaya/

Charnes, L. (2000). We were never early modern. In Joughin, J. (Ed.). Philosophical Shakespeares (pp. 5468). London and New York: Routledge.

Cochoy, F., Giraudeau, M., McFall, L. (2010). Performativity, economics and politics: an overview. Journal of Cultural Economy, 3(2), 139-146.

Cox, J. (2007). From Primitive to Indigenous: The Academic Study of Indigenous Religions. UK: Ashgate.

Dean, J. (2006). Žižek's Politics. New York: Routledge.

Dyen, I. (1965). The Lexicostatistical Classification of the Austronesian Languages. New Haven. [Originally published: 1963].

Eder, J. (1994). Indigenous Peoples, Ancestral Lands and Human Rights in the Philippines. Cultural Survival Quarterly Magazine issue on 18-2 Ethnic Conflict: The New World Order. Retrieved from https://www.culturalsurvival.org/publications/cultural-survival-quarterly/indigenous-peoplesancestral-lands-and-human-rights\#sthash.CBgUTJhE.dpuf 
Espada, J. (2018). The Migrant Mamanwas of Basey Samar: Underneath the Search for Lost Identity. Conference Presentation at the 1st International Multidisciplinary Research Conference, Leyte Normal University, Philippines.

Garvan, J. (1964). The Negritos of the Philippines. Austria: Herman Hochegger Horn Wren: Verlang, Ferdinand.

Harvey, G., and Thompson, Jr. (2005) (eds.) Indigenous Diasporas and Dislocation. Aldershot and Burlington: Ashgate.

Hollingsworth, J. (2019). Taiwan legalizes same-sex marriage in historic first for Asia. CNN Asia. Retrieved from: https://edition.cnn.com/2019/05/17/asia/taiwan-same-sex-marriage-intl/index.html

Jameson, F. (1973). The Vanishing Mediator: Narrative Structure in Max Weber. New German Critique 1, 5289.

Kahambing, J. (2018). Diaspora as Vanishing Mediator: Emancipation of Identity for the Mamanuas of Basey, Samar. In Galang-Pereña, F., Ampil, R., Gonzales, E., \& Lazaro-Zamora, N. (Eds.), Philippines and Asian Studies: Expositions, Explorations, and Expectations (pp. 183-200). Rizal: Word Prints Publishing Services, Inc.

Linguistic Society of the Philippines (1991). Mamanwa Texts. Summer Institute of Linguistics. Pacific and Asian Language Databank.

Masinaring, M.R. (2011). Understanding the Lumad: A Closer Look at a Misunderstood Culture. (Lacorte, G., ed.) Baguio City: Valley Printing Specialist.

Pallesen, A. K. (1985). Culture contact and language convergence. Philippine Journal of Linguistics, special monograph issue 24 .

Picardal, E. (2017). Socio-cultural history of Mamanwa adaptations of Community in Sitio Palayan, Barangay Caucab, Almeria, Biliran. Retrieved from https://www.scribd.com/document/367870325/Socio-culturalHistory-of-Mamanwa-Adaptations-of-Community-in-Sitio-Palayan-Barangay-Caucab-Almeria-Biliran

Polanyi, K. (2001). The Great Transformation, The Political and Economic Origins of Our Time. Boston: Beacon Press. Originally published: 1944.

Ponce, B. (2018a). Speck in the Vast World of Economy and Politics: An Economic Anthropological Study of the Mamanwa in the Philippines. Asia Pacific Journal of Multidisciplinary Research, 6(2), 97-104.

Ponce, B. (2018b). Hitso: Food Ritual and Changes. In Paper Presentations for the Second International Conference on Philippine and Asian Studies: Language, Culture, and Media (p. 11). De La Salle University and Visayas State University, Philippines.

Retome, V. (2018). Katayuan ng Tribung Mamanwa sa Saint Bernard, Southern Leyte. In Paper Presentations for the Second International Conference on Philippine and Asian Studies: Language, Culture, and Media (p. 20). De La Salle University and Visayas State University, Philippines.

Rifkin, M. (2017). Indigeneity, Apartheid, Palestine: On the Transit of Political Metaphors. Cultural Critique, 95, 25-27.

Rose, D. (2009). Dingo Makes Us Human; Life and land in an Australian Aboriginal Culture. New Paperback, Cambridge University Press (digital edition). [Originally published: 1992]

Slater, G. (2018). Assembling the opposition: Organizing struggles against neoliberalism and educational insecurity. Policy Futures in Education, http://dx.doi.org/10.1177/1478210318766949

Smith, A. (2011). Against the Law: Indigenous Feminism and the Nation-State. In Glen Coulthard, Jacqueline Lasky, Adam Lewis, and Vanessa Watts (Eds.). Affinities: A Journal of Radical Theory, Culture, and Action, 5(1). Special Issue on Anarch@Indigenism, 56-69. 
Stoneking, M. (2008). Mamanwa Genetic Composition. Leipzig, Germany: Max Plank Institute of Microbiology.

Tiukinhoy, M.N. (1997). The Culture of the Mamanwas: An Analysis. Ph.D Dissertation, San Nicolas College (Now St. Paul University, Surigao City).

Tomaquin, R. (2013). Indigenous Religion, Institutions and Rituals of the Mamanwas of Caraga, Region, Philippines. Asian Journal of Social Sciences, Arts and Humanities 1 (1): 18-36.

Trinidad, A.R. (2012). Learning to be Indigenous: Education and Social Change among the Manobo People in the Philippines. PhD thesis for PhD in Social Anthropology: The University of Manchester.

Venkateswar, S., Hughes, E., Kidd, C., Kenrick, J., Glauser, B., Waitere, H., McKinnon, K., Singh, S.J. (2013). Introduction. In Sita Venkateswar and Emma Hughes (Eds.), The Politics of Indigeneity: Dialogues and Reflections on Indigenous Activism. Zed Books Ltd.

Watson, J. (2012). Butler's Biopolitics: Precarious Community. Theory E Event, 15(2).

Žižek, S. and Milbank J. (2009). The Monstrosity of Christ: Paradox or Dialectic? (Creston Davis, ed.) Boston, The MIT Press.

Jan Gresil S. Kahambing is a faculty member in the Social Science Unit and Museum Director of Leyte Normal University, Tacloban City. He received all his academic degrees in Philosophy (Magna Cum Laude), Theology (Magna Cum Laude), and Classical Studies (Magna Cum Laude) from the University of Santo Tomas, Manila. His recent publications lean toward Philippine Studies, Posthumanism, and Human Rights Literature. He is involved in the long-term research and extension project entitled 'Documenting the Life E Culture of the Migrant Mamanwa of Basey, Samar' as part of the 'LNU: Lending a hand. Building a future' initiative in cooperation with the United Nations Educational, Scientific and Cultural Organization (UNESCO) and National Commission on Indigenous Peoples (NCIP), Philippines. 